\title{
Exploring discourses of indigeneity and rurality in Mikea Forest environmental governance
}

\author{
Amber R. Huff
}

\begin{abstract}
This article examines discourses of indigeneity and rurality that define and classify different categories of resource users in the context of Mikea Forest environmental governance. Many Malagasy peoples live in, have deep cultural ties with, and directly depend on the island's forests, but Mikea people are the only to be legally recognized as 'indigenous peoples' as defined by Operational Directive 4.20 of the World Bank. In policy documents, scholarship, and media productions, Mikea people are represented as a small, culturally distinct population of primitive forest foragers. In contrast, other subsistence producers living in the region are represented as invasive and harmful to Mikea people and the Mikea Forest environment. However, there are significant incongruities between these representations and local history, cultural norms, and social-environmental realities. While the intent of international norms for indigenous rights in conservation and development contexts is to mitigate risk of harm and improve democratic participation among historically underrepresented peoples, this case highlights how imposed notions of indigeneity can in some cases actually increase local vulnerabilities. Mikea Forest environmental policies should be amended to mitigate risk of insecurities faced by a broad range of forest residents, Mikea and non-Mikea, due to socio-political exclusions, restricted livelihoods, and reduced territorial rights.
\end{abstract}

\section{RÉSUMÉ}

L'objectif de cet article est d'examiner comment sont définies et classifiées les différentes catégories d'utilisateurs des ressources dans le cadre de la mise en place de politiques publiques à l'échelle de la forêt des Mikea et dans les discours sur l'indigénisme et la ruralité qui y sont associés. De nombreux Malgaches vivent, ont des attaches culturelles et dépendent directement des îlots forestiers pour leur subsistance ; néanmoins seuls les Mikea sont légalement reconnus comme des "peuples autochtones " tels que définis par la directive opérationnelle 4.20 de la Banque Mondiale et auraient dès lors des droits particuliers sur le territoire qu'ils occupent, y compris les forêts. Dans les textes des politiques environnementales ou dans les médias, les Mikea sont présentés comme membres d'un peuple autochtone doté d'une culture inédite et qui a adopté un mode de vie original alors que les populations voisines sont perçues comme des envahisseurs perturbant I'organisation sociale et les forêts des Mikea, Il existe toutefois des décalages importants

\author{
The University of Georgia \\ 250A Baldwin Hall, Jackson Street \\ Athens, Georgia, U.S.A 30602-1619 \\ E-mail: amber.rosalyn@gmail.com
}

entre ces représentations et les réalités du terrain : Ies fondements de l'identité locale ne correspondent pas aux définitions officielles de l'autochtonie présentée dans les documents du développement. Les Mikea et les populations voisines sont en fait largement interdépendants et tous pratiquent un éventail d'activités économiques qui varient en fonction des saisons, des compétences ou des demandes du marché. Contrairement aux représentations officielles présentant la culture des Mikea comme étant unique et autonome, les Mikea appartiennent aux mêmes clans et partagent les mêmes pratiques que leurs voisins jugés illégitimes quant à la gestion des territoires. L'histoire montre en outre une longue participation des peuples Mikea aux échanges commerciaux régionaux et mondiaux et des échanges réguliers avec les missionnaires. L'objectif des normes internationales pour les droits des peuples autochtones est de réduire la vulnérabilité des peuples sous-représentés dans les instances officielles et d'améliorer leur participation démocratique au sein de ces instances; notre recherche montre que les notions imposées d'autochtonie peuvent accentuer la vulnérabilité des peuples à l'échelle locale dans certaines situations. Les politiques environnementales concernant la forêt des Mikea devraient être améliorées pour prendre en compte I'insécurité que rencontre une grande partie des résidents de la forêt, Mikea et non Mikea. Les acteurs de la conservation et du développement pourraient mettre en place des politiques plus justes et plus démocratiques, et devraient chercher à atténuer les conséquences négatives des politiques déjà en place.

\section{INTRODUCTION}

In Madagascar, protected forests are contested spaces where powerful discourses and material struggles meet. Madagascar's forests are presented by different powerful groups as global goods in crisis (Myers 1992, Ganzhorn et al. 2001, Harper et al. 2007), as wild natural spaces teeming with imperiled species of plants and animals (Myers et al. 2000, Mittermeier et al. 2008: 147), as threatened suppliers of valuable ecosystem services (Laurance 1999, Bodin et al. 2006) and as critical reserves of oil, titanium, and sequestered carbon that will facilitate national economic development and poverty alleviation if they can be managed sustainably (Norris 2006, Reyneke and Wallmach 2007, Ferguson 2009).

In narratives of general environmental crisis throughout Madagascar, such assertions of value are often juxtaposed with 


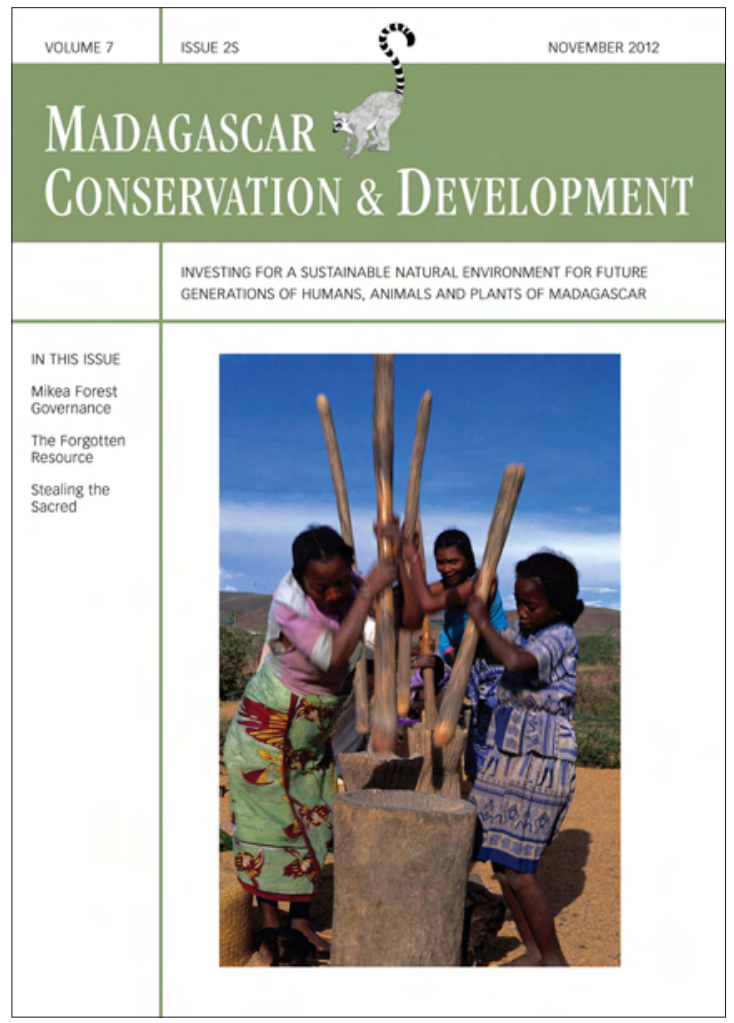

Madagascar Conservation \& Development is the journal of Indian Ocean e-Ink. It is produced under the responsibility of this institution. The views expressed in contributions to MCD are solely those of the authors and not those of the journal editors or the publisher.

All the Issues and articles are freely available at http://www.journalmcd.com

Contact Journal MCD

info@journalmcd.net for general inquiries regarding MCD funding@journalmcd.net to support the journal

Madagascar Conservation \& Development Institute and Museum of Anthropology University of Zurich

Winterthurerstrasse 190

$\mathrm{CH}-8057$ Zurich, Switzerland

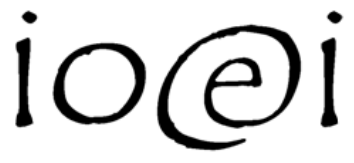

Indian Ocean e-Ink

Promoting African Publishing and Education www.ioeink.com

Missouri Botanical Garden (MBG)

Madagascar Research and Conservation Program BP 3391

Antananarivo, 101, Madagascar 
statements of threat, attributing progressive environmental degradation and impending crisis to the behavior of rural people who produce for subsistence or who use extensive agricultural production strategies. In these narratives, Malagasy subsistence producers are represented in terms of a 'discourse of rurality' (Pratt 1996), as a relatively homogenous class of causal agents whose generalized poverty, patterns of migration, inefficient modes of subsistence, and high birth rates are contributing to a "tragedy of the commons" scenario (Hardin 1968, Durbin 1999: 276). According to these narratives, without significant environmental action the future will see progressive forest fragmentation, increased loss of habitats and endemic species, generalized ecosystem degradation, and ecological and economic collapse (Smith et al. 1997, coe 1998, Hannah et al. 1998: 30-31, Styger et al. 1999: 258, Harper et al. 2007: 325-326)

Descriptions of deforestation in the Mikea Forest region of southwestern Madagascar feature representations of destructive rural subsistence producers as well. Since the late 1990s, a familiar crisis narrative has justified the development of environmental policies that criminalize some important livelihood activities, and have increasingly restricted smallholders' access to territory and forest resources. But the Mikea Forest environmental narrative is unique in Madagascar because of the additional legal categorization of Mikea people as 'indigenous peoples' (Ferguson 2009). Although a great many Malagasy peoples live in, have deep cultural ties with, and directly depend on the island's forests, Mikea are the only to be formally recognized as 'indigenous peoples' in Madagascar, as defined by Operational Directive 4.20 (OD 4.20) of the World Bank (World Bank 1991, Eaux et Forêts 2003:6, WWF 2003: 5, Ferguson 2009: 17, Repoblikan'i Madagasikara et al. 2010a).

While indigenous or 'true Mikea' are represented in idyllic terms as living in adaptive ecological balance as pristine foragers, other residents' attitudes, behaviors, histories of residency are glossed and presented in stark contrast to idealized Mikea. People who are variably referred to as non-Mikea, 'false Mikea', and 'migrants' are represented as encroaching on Mikea lands, negatively influencing Mikea culture and endangering traditional subsistence and spiritual practices by causing deforestation, by introducing farming, currency, commerce, and consumer goods, and by committing violent acts of theft against Mikea (WWF 2003: 8).

However, the discourse of Mikea indigeneity and antagonistic descriptions of Mikea vis-à-vis other residents of the region are at odds with local conceptions of history, sociality, and human-environment relationships, and they gloss significant diversity of lifestyle, livelihood, and personal experience among people who live in the Mikea Forest region. In the development of projects that receive funding from the World Bank, the presence of peoples classified as 'indigenous peoples' requires the establishment of protocols to ensure that peoples who selfidentify as indigenous or who have been historically marginalized do not experience increased vulnerability (World Bank 1991). While the ethical intent of such guidelines is to ensure that people's rights, dignity, and interests are respected in the development of policies that affect them, this case highlights how preconceived notions of indigeneity, formalized in policy, can work to increase social and material risk among relatively disadvantaged peoples in particular contexts.
This article explores discourses of rurality and of Mikea indigeneity in Mikea Forest environmental protection policies and resource management practices from an anthropological perspective. Because of long-standing concerns with issues of power and inequality, with the contingency of socio-cultural forms and transformations, and with understanding human diversity and plurality in human experience, anthropologists are positioned to both critically and empirically examine claims that on the surface may appear "common sense" (Herzfeld 1998, 2001: 5). Compelling and widely accepted claims, or "received wisdoms" can generalize complex processes and obscure "a complex political economy of winners and losers" (Leach and Mearns 1996: 442, Adger et al. 2001: 687-688). By comparing local views and experience to the discourses that inform particular policies and practices, anthropological research can reveal problems with received wisdoms that simultaneously preclude more nuanced understandings of human social and environmental interactions and inhibit consideration of a variety of alternative viewpoints.

First, I provide background on the cultural geography of the Mikea Forest region and discuss the evolution of regional environmental governance since the 1990s. Next, I discuss the cultural origins of contemporary discourses of Mikea indigeneity, and discuss the ways in which discourses of rurality and indigeneity define and classify different categories of resource users in this context. Third, I evaluate these representations using information from secondary sources and ethnographic evidence regarding history, livelihoods, and norms of identity in the northern and central Mikea Forest region. Finally, I will discuss some of the challenges involved in applying international norms for indigenous rights in this context, and suggest ways that policy planners and conservation practitioners can address gaps between policy prescriptions, conservation and development practice, and local experience in the Mikea Forest region.

The information presented in this article is based on a review of relevant secondary sources, qualitative content analysis of policy documents, and information gained in focus groups and interviews over the course of eleven months of ethnographic fieldwork in southwestern Madagascar in 2007-2009 as part of a larger research project examining relationships among social change, livelihoods and human health in the Mikea Forest region. Focus groups were conducted in early 2009 in order to guide the development of a survey instrument for assessing exposure to social and environmental stressors (results not presented here), but, like interviews and other forms of data, results of these focus groups are helpful to understanding local perceptions and policy outcomes. Participants in semi-structured and unstructured interviews included self-identifying Mikea, Masikoro, and Vezo people living near protected area boundaries, regional security personnel and government administrators, and conservation and development practitioners working in the region.

\section{THE MIKEA FOREST REGION: IDENTITY, LIVELI- HOODS, AND THE EVOLUTION OF ENVIRONMEN- TAL GOVERNANCE}

THE CULTURAL GEOGRAPHY OF THE MIKEA FOREST REGION.

The Mikea Forest region (Figure 1) lies east of the Mozambique Channel between the cities of Toliara and Morombe in southwestern Madagascar. City dwellers refer to this region, 
along with most of rural Madagascar, as Ambani'vohitse (below the hills), a term without geographic specificity denoting isolation from city centers and state infrastructure. The Mikea Forest itself is an expanse of dry deciduous and spiny forest occurring on unconsolidated sands. The regional landscape is heterogeneous and anthropogenic, composed of coastal dunes and mudflats, limestone flats, mangroves, and spiny xerophytic scrub on the western coast; forested dunes, dense and viny dry deciduous forest, rain-fed wetlands, and dry, spiny scrubland in the Mikea Forest between the coast and the eastern savanna; and woodland, woody savanna, spring-fed irrigated rice fields (tanambary) and savanna grassland to the east of the Mikea Forest.

In the Masikoro and Vezo dialects of Malagasy, which are also spoken by Mikea, the word karaza means 'a type' (Astuti 1995b: 9). There are karaza of all sorts of things: fruits (mangoes, oranges), animals (species), crops (varieties), and peoples (ethnicities). When speaking of people locally, karaza most often refers to a primary cultural identity and a lifestyle associated with that identity. In the Mikea Forest region, three primary cultural identities are normatively associated with different ecological niches and primary livelihood activities. These primary identities include Mikea, Vezo, and Masikoro.

Mikea self-identify and are identified by their neighbors as people of the Mikea Forest (Alamikea). Vezo describe themselves as 'people of the sea' (olo andriake) who practice marine foraging on the rich reefs that hug the west coast of Madagascar. Masikoro describe themselves as people of the savanna and woodland to the east of the Mikea Forest, special-

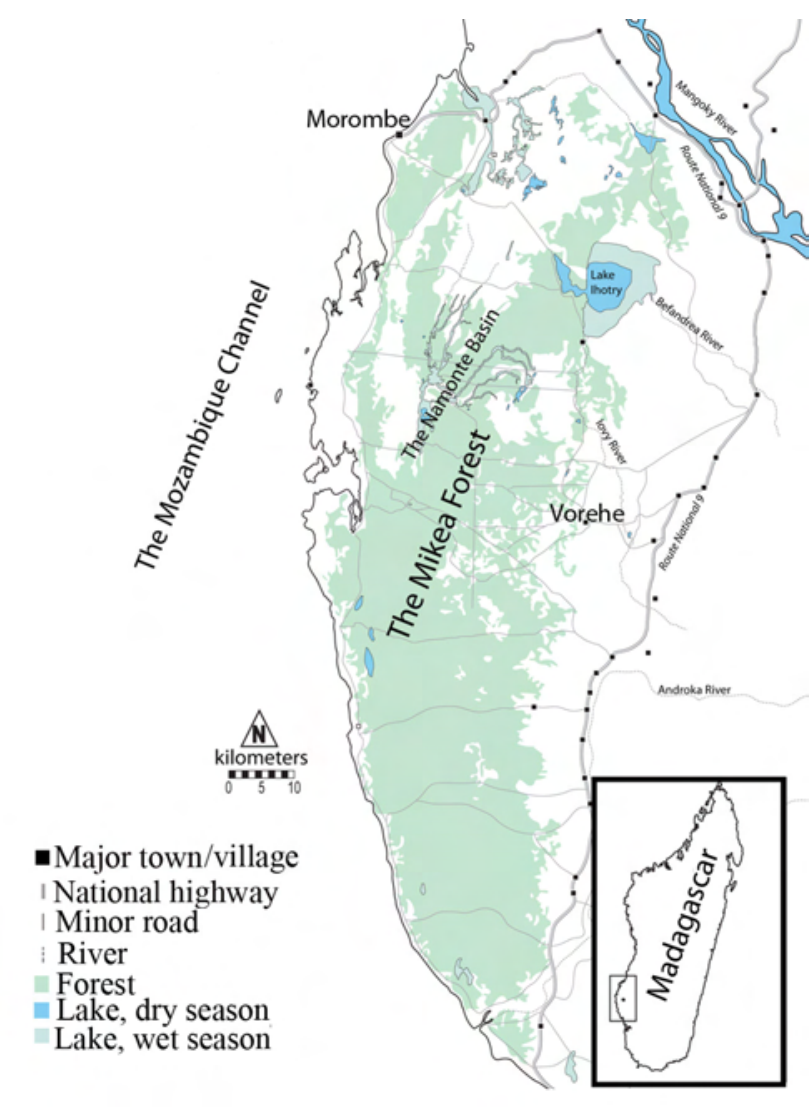

FIGURE 1. The Mikea Forest region, showing major geographical features, major towns and villages, and roads. Minor towns and hamlets are not shown. Adapted with permission from a map of the Mikea Forest region by Bram Tucker; forest extent from 1994 Landsat images processed by James Yount. izing in farming and raising cattle and other livestock. People self-identifying as Mahafaly, Tandroy, Tanosy, and Tesaka also live in the Mikea Forest region, practice similar livelihoods, and often live in settlements that are considered to be historically Mikea, Vezo, or Masikoro. These so-called 'immigrant' identities are associated with migration into the region in the colonial and post-colonial periods in response to political and ecological factors, and in response to market demand for specific wild or agricultural products.

According to local oral historians, contemporary Mikea, Vezo, and Masikoro share common heritage (Tucker 2003: 199), and the emergence of Mikea, Vezo, and Masikoro identities was contemporaneous with the pre-colonial rise of the Maroseraña and Andrevola dynasties in southwest Madagascar in the seventeenth century (Yount et al. 2001, Tucker 2003). In the pre-colonial period, Masikoro identity became associated with "loyal, tribute-paying vassals to the kings" (Tucker et al. 2011: 293). Others sought to avoid political incorporation, risk of slave and cattle raids, frequent food shortages, and accusations of sorcery by resorting to mobile marine foraging, and to forest-based terrestrial foraging, herding, and farming (Tucker 2003: 199). Many Mikea oral historians describe their ancestors as farmers and semi-nomadic coastal pastoralists who sought refuge, security, and subsistence in the Mikea Forest, but who also maintained social ties and extensive trade relationships with people living outside of the forest. Astuti (1995a, b) discusses Vezo and, to a lesser extent, Masikoro identities as processual in nature; one's identity is not simply something that one 'is' because of birth or descent, but is a characteristic of one's self that develops in the context of what one knows and does and where one lives at a particular time. Some self-identifying Mikea people express identity in similar terms, on the basis of forestbased residence and/or sophisticated knowledge of forest and foraging. But, as Yount et al. (2001) explain, there are other ways in which people self-identify as Mikea. These explanations "situate the informant within a line of descent or a village of origin that itself has a Mikea history of life in the forest" (Yount et al. 2001: 262). Thus, self-identification as Mikea may be processual, as discussed by Astuti (1995a, b), but it may also be based in residential, historical, and/or genealogical explanations. In addition, most people who self-identify as Mikea also identify as Vezo or Masikoro, thereby alluding to personal histories, to livelihood diversification (discussed below), or historical migrations of particular groups of people. As Poyer and Kelly (2000: 168-169) observe, identities of self-identifying Mikea people may shift for various reasons, including avoidance of stigma or discrimination, as one moves between forest and villages.

Despite contemporary norms associating Mikea, Vezo, and Masikoro identities with ecologically specialized lifestyles, members of all three groups (and members of other groups as well) are highly mobile and practice "productive bricolage" livelihood strategies (Batterbury 2001: 483). Throughout the twentieth century, Mikea and their neighbors responded ambitiously to market booms for butterbeans (kabaro) in the interwar period and the 1960s, silk (kohoke) harvesting and processing in the 1920s and again in the early 2000s, cotton (hasy), and maize (tsako) from the 1970s to the early 2000 s (Ottino 1963, Hoerner 1981, 1987, Tucker 2001, Blanc-Pamard 2009). Even so, for most people, the majority of production has remained very diversified and subsistence-oriented or oriented 
toward regional markets. This is due to a combination of social, environmental, and economic factors, including seasonality, stochasticity of rainfall and markets, poor infrastructure resulting in high transport costs, dependency on relationships with brokers (often Malagasy Indo-Pakistani) who buy bulk produce at very low prices and sell high, the exploitive social relations of sharecropping, and the high debt-risk incurred by intensive agricultural production (see Ottino 1963 for early description). In any given village residents are likely to practice a shifting combination of horticulture, animal husbandry, freshwater fishing, forest foraging, marine foraging, manufacturing, market commerce, and wage labor (Tucker 2001).

THE EVOLUTION OF MIKEA FOREST ENVIRONMENTAL

GOVERNANCE. In recent years, interest in converting the Mikea Forest into a protected area (PA) and later a national park has been stimulated by national goals to increase the amount of forest under protection in Madagascar (Raik 2007), and has been justified citing a significant reduction in regional forest cover since the 1970s due to forest cutting and burning for pasturage, charcoal production, and especially for hatsaky, swidden maize production, by subsistence farmers and agropastoralists (Seddon et al. 2000, Milleville et al. 2001, Aubry and Ramaromisy 2003, Blanc-Pamard 2009).

In order to slow deforestation, between 1998 and 2001 a blanket ban on hatsaky maize production was enforced by an intercommunal NGO called FiMaMi (Fikambanana Miaro ny Ala Mikea, or Society for the Protection of the Mikea Forest). Between 2001 and 2003, a Commission mixte (Joint commission), funded by the United Nations Development Programme (UNDP), and formed through collaboration among FiMaMi and representatives of various national agencies, the Worldwide Fund for Nature (WWF) and Conservation International $(\mathrm{Cl})$, members of the Malagasy military, the gendarmerie, and the courts system, oversaw enforcement of the hatsaky ban (WWF 2003).

By 2003, the Mikea Forest maize boom, which was fuelled primarily by export demand, had effectively ended in the northern and central Mikea Forest. Mikea and others living in the region had generally stopped clearing forest for new hatsaky or had resorted to clandestine smaller-scale maize cultivation.

In 2007 the Mikea Forest Protected Area agreement, a temporary order of protection, was formalized, establishing a large area of protection, Complexe Mikea, of over 370,000 hectares with a buffer zone surrounding it. Within the PA, zones of no use (noyau dur), controlled use (zone d'utilisation contrôlée, or ZUC), controlled habitation (zone d'occupation contrôlée, or ZOC), and ecotourism were created in preparation for the PA's transition to national park status (Repoblikan'i Madagasikara 2007).

Between 2007 and 2009, PA boundaries were under negotiation. In late 2008, I was told by the director of the Mikea Forest bureau of Madagascar National Parks (MNP) that no reliable map existed at that time because of ongoing negotiations regarding potential mining activities. On maps of the Mikea National Park created in early 2009 (Figure 2), the size of the PA had been decreased to just under 185,000 hectares, and a large mining concession was shown to adjoin the eastern buffer zone (FTM/ Madagascar National Parks 2009).

Project planners estimate that approximately 130,000 Malagasy people will be affected by restrictions on resource use associated with the creation of the Mikea National Park and the surrounding PA (Repoblikan'i Madagasikara et al. 2010b: 12). Resource use restrictions affect important economic and health-related activities, including the cutting of vegetation for charcoal production; hunting bushpig (Iambo; Potamochoerus larvatus), wild guinea fowl (akanga; Numida meleagris), and small mammals; collecting fuel wood; collecting medicinal plants; collecting potable water; collecting materials for house construction; fishing; pasturing livestock, and collection of natural materials used for weaving baskets and mats (Repoblikan'i Madagasikara et al. 2010b: 12). People whom planners refer to as the 'autochtonous Mikea population', are exempt from such restrictions because, according to policy documents, as hunter-gatherers "their traditional practices and exploitation of resources are in harmony with their natural habitat," and are considered compatible with the management objectives of the PA (Repoblikan'i Madagasikara et al. 2010b: 9).

\section{REPRESENTING PEOPLE: LINKING HISTORICAL DISCOURSE, POPULAR CONVENTION, SCHOLAR- SHIP, AND POLICY}

VAZIMBA ASSOCIATIONS AND MIKEA INDIGENEITY

IN POPULAR CULTURE AND SCHOLARSHIP. The concept of Mikea indigeneity did not originate among Mikea people, but has been constructed at different socio-political scales, and also at different time scales (Yount et al. 2001, Tucker 2003). On a national level, the idea of Mikea indigeneity is linked to related streams of Malgachisant scholarship, as well as to widespread popular beliefs about ancient origins, primitivism, and cultural distinctiveness of foraging people in general and Mikea people in particular (see Moyoun and Francelle 1999a, b, Rarojo 1998). Notions that Mikea are an isolated and culturally primitive people, a relict population of elusive pygmies, or even mysterious semihumans, are common conventions outside of the Mikea Forest region, and are relevant to popular ideas about Malagasy natural and cultural history, mythology, and nationalism (Tucker 2003).

In Madagascar, popular notions of Mikea indigeneity revolve around what Tucker (2003: 194) terms the "Vazimba ${ }^{1}$ hypothesis" of Mikea origins. According to one stream of lore, Vazimba were a group of primordial inhabitants widely believed to have lived in the Malagasy highlands before being driven to peripheral areas of the island by later proto - Malagasy immigrants of "superior... intellect and ability" (Grandidier 1920: 209). While many Vazimba and their descendants purportedly assimilated into Malagasy society, those who remained in isolated areas came to be labeled 'owners of the land who came before', tompontany taoloha, implying direct descent from ancestral Vazimba.

In a fundamental sense, this stream of Vazimba lore originated simultaneously in Europe and Madagascar in the pre-colonial period, during a time when people all over the world were interacting through trade and transformative cultural exchange and synthesis. According to Berg (1977: 7-8) and Graeber (1999: 329-330), legends describing a race of bizarre pygmies living in isolation as well as stories of dark spirits lurking in the wilderness of Madagascar were reaching Europe by the end of the eighteenth century, even before the first European missionaries had reached Madagascar's interior regions and began transcribing oral histories. Such legends have become part of the national historical cannon. They have been institutionalized in state histories including in the Tantara ny Andriana eto Madagascar 


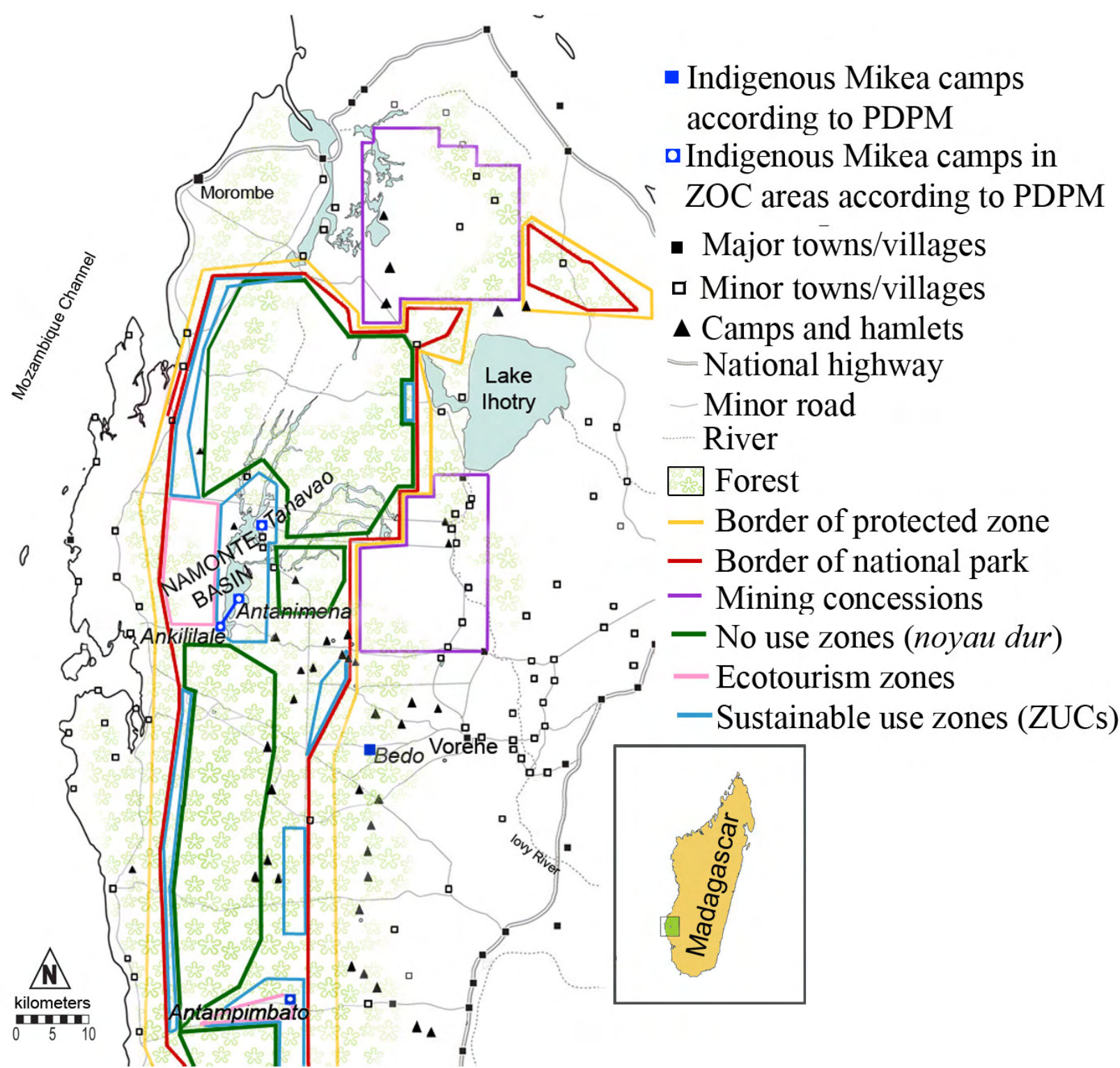

FIGURE 2. The north and central Mikea Forest Region, showing major geographic features, PA zoning, mining concessions, and major and minor settlement sites. Adapted from maps included in the Plan de développement de la population autochtone Mikea (Repoblikan'i Madagasikara et al. 2010a), from Carte de zonage du Parc National Mikea (FTM/Madagascar National Parks 2009), and from a map of the Mikea Forest region by Bram Tucker; forest extent from 1994 Landsat images processed by James Yount).

(Malzac and Callet 1908), and have been part of the forma history curriculum of Malagasy schoolchildren for generations (Berg 1977, Graeber 1999, Tucker 2003). According to Kelly and Poyer (1999) and to Tucker (2003), with a lack of alternate written historical sources and little archaeological evidence, the sometimes didactic, sometimes alternately verifiable, and sometimes fictional information contained in formal histories has been repeated and reinvigorated subsequent generations of foreign and Malagasy scholars, often without attribution. According to Sarah Dugal, whose doctoral thesis (2004) documents several versions of the 'Vazimba story' in historical documents and oral histories, the only logical connection between Mikea people and Vazimba is that both are purported to be or have been foragers (personal communication).

The institutionalization of ideas that link such legends to Mikea people is evidenced by the fact that scholars have continued to attribute assumed primitivism to the idea that Mikea people are relict descendants of Vazimba since at least the early twentieth century. Scholarly depictions of Mikea as relict or primitive take two basic forms, both of which are influenced by historical 'Vazimba' associations and notions of progressive social evolution. Some authors and journalists directly and literally attribute assumed primitivism to the idea that Mikea are descendants of Vazimba (Birkeli 1920, 1939, Koechlin 1975, Faroux and Rabedimy 1985: 2 [discussion of "Les Mikea traditionne/s"], Stiles 1991, 1998, Godefroit 1998: 83, Rarojo 1998, Mouyon and Francelle 1999a, b, Blench 2008).

Other authors accept the relatively recent advent of Mikea as a cultural identity, and acknowledge the historical origin of this identity in refugeeism and resistance of authoritarian rule, as well as kinship with neighboring Vezo and Masikoro (Faroux and Rabedimy 1985: 2 [discussion of "Les pseudo-Mikea"], Blanc-Pamard 2002: 220, Blanc-Pamard et al. 2005: 9). Yet these authors also describe Mikea using classic essentialisms and language that evokes imagery of the relict primitive, describing Mikea in terms of wildness, primitivism, or mysticism, in terms 
of indigeneity, or as living in ecological harmony in the mode of the "ecologically noble savage" (Redford 1991: 26). Popular conventions regarding Mikea primitivism as well as both of these streams of pro-primitivist scholarship have significantly influenced representations of the "Mikea population autochtone" vis-à-vis other residents of the Mikea Forest region in environmental policy narratives (see Eaux et Forêts 2003, WWF 2003, Repoblikan'i Madagasikara et al. 2010a, b).

REPRESENTATIONS OF INDIGENEITY AND RURALITY IN MIKEA FOREST ENVIRONMENTAL POLICY. Received wisdoms regarding Mikea became streamlined and formalized in policy as interest in establishing a Mikea Forest protected area began to coalesce concurrently with the planning of the third phase of Madagascar's National Environmental Action Plan. Contemporary international norms regarding indigenous peoples are embodied in the influential 1989 ILO Indigenous and Tribal Peoples Convention no. 169 (not ratified by Madagascar), which lays out basic principles for ensuring the rights of people who self-identify and are recognized by others as indigenous and tribal peoples. These principles include criteria for the identification of indigenous and tribal peoples, recognition of rights to non-discrimination, rights to special protection in order to safeguard culture, rights to consultation, and rights to free, prior and informed participation in political processes that affect them (Anaya 1991, 2004, Bowen 2000, Pelican 2009). Self-identification as indigenous is considered both a right of indigenous peoples and a fundamental criterion for the identification of peoples to whom these principles are meant to apply (World Bank 1991: 1, Hodgson 2002:1038, Sarafaty 2005: 1803).

International customary norms can 'steep into domestic law' in countries such as Madagascar that have not ratified international conventions. This happens when lenders such as the World Bank attach special conditions to aid, or incorporate operational policies into aid agreements to promote compliance with international customary law in countries receiving financial and technical assistance (Sarafaty 2005: 1795). The World Bank, a partial funder of the PA, maintains special operational guidelines for projects that affect people who are "indigenous peoples, tribes, ethnic minorities, or other people whose social and economic status restricts their capacity to assert interests and rights in land and other productive resources" (World Bank 1991: 1). In accordance with World Bank Operational Directive 4.20 (OD 4.20), national recognition of Mikea people as indigenous contractually necessitated the creation of a development framework by which the dignity, rights and 'informed participation' of Mikea in the development of policy would be ensured as plans to establish the Mikea Forest PA progressed (World Bank 1991). In practice, this meant that project planners would have to establish criteria for distinguishing between those who are Mikea and who are not, a difficult task considering the complexities of Malagasy systems of identity.

According to discussions with Madagascar National Parks personnell in 2007-2009 and project documents published by the World Bank, including Plan de développement de la population autochtone Mikea (PDPM) and the Cadre fonctionnel de procédures de sauvegarde pour le projet de création du Parc National Mikea (referred to as a 'resettlement plan'), rights of resource use and habitation within PA boundaries hinge on identity, particularly whether or not one's lifestyle and site of residence qualifiy one as a member of the "Mikea population autochtone" (Repoblikan'i Madagasikara et al. 2010a, b). The PDPM identifies the entire indigenous Mikea population as 923 individuals living in forest 'camps' of Ankililale, Antanimena, and Tanavao, located in two controlled habitation areas (ZOCs) in the north-central Mikea Forest, Antampimbato, in a ZOC to the south, and Bedo, located outside of the eastern boundary of the PA near the village of Vorehe (Repoblikan'i Madagasikara et al. 2010a: 75).

According to the PDPM, autochthonous Mikea are defined as unique and culturally different from other Malagasy, maintaining distinct customs and social institutions, subsisting primarily by foraging for wild foods with primitive tools, and depending on the forest for renewable resources, including medicinal plants (Repoblikan'i Madagasikara et al. 2010a: 33, 82-84). The authors of the 2010 resettlement plan likewise identify Mikea as "a local indigenous population living in precarious conditions and dependent only on gathering [natural resources of the forest] and hunting [game]" (Repoblikan'i Madagasikara et al. 2010b: 12, author's translation). Mikea are further identified as spiritually, culturally, socially, and economically dependent on land and forest resources and are explicitly discussed as separate from the broader national context of Malagasy society. This is illustrated by the key statement made by project planners that an individual or community will lose the protected status as a "population autochtone" when they choose to "emerge from the forest and adopt the way of life and civilization of the outside world" (Repoblikan'i Madagasikara et al. 2010b: 22, author's translation).

In policy, the category of the Mikea population autochtone and the true Mikea/false Mikea dichotomy are based on a highly selective process by which information and ideas that support the fictive notion of Mikea as a culturally distinct group of primitive, environmentally harmonious hunter-gatherers is highlighted and emphasized, while information that is contrary to this representation is de-emphasized or omitted. Highlighted characteristics include forest residence, natural resource dependency, selected foraging activities, sociopolitical marginalization, and material poverty. Information that is de-emphasized or omitted includes (but is not limited to) the extent of heterogeneity and diversification of livelihoods among Mikea; the extreme seasonality of foraging in the Mikea Forest; the importance of participation in markets for goods, sevices, and labor; the inaccessibility of state infrastructure and development projects, and the fact that most people who selfidentify as Mikea simultaneously identify as Vezo or Masikoro. Furthermore, the Plan de développement de la population autochtone Mikea (PDPM) estimates the number of Mikea to be less than one thousand people living in a few scattered camps in and near the forest. On PA maps that include settlements, with the exception of a few villages in the Namonte Basin area and the southern Mikea Forest, all villages and hamlets within the park boundaries and buffer zones have been omitted, giving the impression that this area is either sparsely populated or unpopulated (Repoblikan'i Madagasikara et al. 2010a). In reality, thousands of self-identifying Mikea and others living in permanent villages, hamlets, and seasonal camps are omitted from policy consideration and rights to land and natural resources.

While members of the Mikea population autochtone are described as living in adaptive ecological balance as exclusive or nearly exclusive foragers, the attitudes, behaviors, histories 
of residency of other people living in the region are glossed by a simplified narrative of rurality and presented in stark contrast to idealized indigenous Mikea. Non-Mikea, 'false Mikea,' and 'migrants' are represented as encroaching on Mikea lands, negatively influencing Mikea culture and endangering 'traditional' subsistence and spiritual practices by causing deforestation, introducing farming, currency, commerce, and consumer goods, and committing violent acts of theft against Mikea (WWF 2003: 8).

\section{ETHNOGRAPHIC EVIDENCE AND THE GOVERN- ANCE GAP}

MIKEA EXPERIENCES VIS-À-VIS THE IDEA OF THE MIKEA POPULATION AUTOCHTONE. The practice of representing Malagasy people through discourses of rurality and discourses of Mikea indigeneity developed apart from the lived experience of residents of the Mikea Forest region. As a result, there are significant incongruities between official representations of identity and lifestyle that have guided regional policy production on one hand, and local history, cultural norms, and social-environmental realities on the other. People who self-identify as Mikea do not self-identify with the category of the Mikea population autochtone. The highly selective presentation of information in regional environmental policy is accompanied by three particular types of imagery - imagery of primitivism, of traditionalism, and of vulnerability - in order to substantiate claims that members of the Mikea population autochtone are distinct from other Malagasy people, as well as culturally threatened by other Malagasy living in the region.

There is a great deal of variation among people who identify as Mikea in the accessibility of different technologies (hand tools, firearms, oxcarts, rice threshers, electric generators), in degrees of reliance on foraging as a component of subsistence portfolios (along with farming a number of varieties of food, rearing livestock, marketing, and wage labor), and the degree to which people engage in different forms of commerce (mobile retailing, market-day selling and buying, agricultural production or bulk foraging for sale to regional wholesalers). Barter, foraging, and other forms of dependence on forest resources are not locally considered to be indicators of cultural uniqueness or primitivism, but are ubiquitous among people who live in the Mikea Forest region, regardless of stated identity, as components of flexible and diversified livelihoods that must compensate for seasonality, stochasticity of rainfall, and unstable regional markets for goods, produce, and labor.

In addition to the imagery of primitivism, authors present imagery of traditionalism, citing veneration of ancestors and respect of clan elders, and the maintenance of particular social institutions and cultural practices as characteristics of indigenous Mikea (Repoblikan'i Madagasikara et al. 2010a: 21, 2010b: 22). The imagery of traditionalism reinforces the notion that members of the Mikea population autochtone are oldfashioned, lacking modern consciousness and worldviews. The inclusion of communication with ancestors, respect of elders, spirit posession (tromba) and various types of ceremonies for healing and to mark rites of passage (bilo, savatse, soro), as additional characteristics for identifying Mikea seems very odd considering that, although the names of particular ceremonies may vary by regional dialect, these are well-documented as common practices throughout the southwest, and throughout the whole of Madagascar (see Ottino 1963, Bloch 1971, FeeleyHarnik 1986, Campbell 1992, Astuti 1995a, 2000, Sharp 1995, Lambek and Walsh 1997, Lambek 1998, Middleton 1999, Cole 2001, Dina 2001, Emoff 2002, Sirven 2006, Graeber 2007, Astuti and Harris 2008, Tucker et al. 2011).

Authors of the PDPM and the resettlement plan describe Mikea as people as experiencing exceptional vulnerability due to social marginalization and material poverty caused or exacerbated by the purportedly invasive and culturally corrupting influences of non-Mikea people. While many Mikea do experience a high degree of socio-political marginalization and material poverty, the causes are complex and cannot be reduced to simple antagonism by their neighbors, who face a number of the same challenges as Mikea. Mikea often discuss the forest as a space of relative refuge from state violence and exploitation, as well as a source of diverse livelihoods. People who live in villages and camps within the forest often express pride in possessing knowledge of forest-based subsistence and the ability to survive periods of economic or environmental hardship through foraging. There have however been trade-offs; by continuing to live in relatively isolated areas to avoid violence and exploitation, Mikea are isolated from state and non-state infrastructure (public health services, schools, development projects) to which they may desire access, and experience a high degree of socio-political exclusion. Mikea are unlikely to speak French or the official dialect of Malagasy, and are less likely than others to be literate or bureaucratically competent.

Across the region, forest-based Mikea are stereotyped not as primitive or culturally distinct, but as very materially poor, as lacking basic education, as likely to possess only dirty or tattered clothing, and as likely to be dirty from a lifestyle that involves tuber digging or infrequent bathing (some forest villages and camps are located several kilometers from water sources). People identifying as Mikea experience frequent discrimination and discuss difficulty earning fair wages for labor, being cheated in marketplace transactions, and being harassed by civil defense personnel. Mikea people are considered easy targets for bandits and corrupt outsiders who demand bribes because Mikea live in the forest or on the social margins of villages, often lack up-todate passports and licenses, and have relatively little access to legal protection (Tucker et al. 2011: 300).

The hatsaky maize ban has been particularly problematic for many Mikea living within the forest. Direct effects include the elimination for many of their largest source of cash income, and greatly reduced access to the most nutritious non-foraged staple food. People living across the region frequently attribute increased crime incidence with the crack-down on maize production, as some people (primarily young men from hardstrapped savanna villages) have sought alternative sources of income by resorting to banditry and cattle theft. Increased incidence of banditry and cattle theft since the advent of the hatsaky maize ban has led residents of some forest villages to abandon or hide cattle ownership as a means to protect themselves from the attention of criminals. For Mikea who have abandoned even very small cattle stocks, this has meant removing their most significant form of wealth storage for the sake of personal and household security.

At the same time, people dependent on subsistence production that live in the north and central Mikea Forest region 
have few alternative livelihood options. Institutional capacity building for rural development efforts has primarily focused on more densely populated areas to the east and southeast of the Mikea Forest near Route Nationale 9, where transitions to intensive cotton, manioc, maize, rice, pulses, and sustainable biofuel and charcoal production are supported by a number of national and international NGOs. As a result, people who are the most dependent on forest resources and face the most potential difficulties due to livelihood restrictions face significant, and often absolute, barriers to accessing infrastructure that could in some cases smooth transitions. Such infrastructure might involve equitable financial institutions and credit markets; markets for seed, agricultural inputs, and agricultural outputs; reliable water sources for irrigation, and access to public services, including transportation, education, health services, and agricultural extensions (Zeller et al. 2000: 10, Dear and McCool 2010: 106-107).

In regional environmental policies, particular discourses of Mikea indigeneity, primitivism, traditionalism, and vulnerability conceptually alienate the Mikea from broader Malagasy society and from the cultural milieu of the Mikea Forest region. These policy representations deny Mikea people options, agency, and what Lambek (1998: 106) terms "historicity." The implication is that people who become foragers culturally devolve (Lee and Hitchcock 2001: 267), and step out of history into a more "authentic" (Wilmsen 1989: 8) social order that is less dynamic and more natural. The foraging mode of subsistence is presented as ahistorical, equated with isolation not only from cities, infrastructure or broader social institutions, but with "remoteness from the flow of history" itself (Wilmsen 1989: 8).

OPERATIONAL DIRECTIVE 4.20 AND THE MIKEA FOREST GOVERNANCE GAP. The philosophical underpinnings international customary law regarding indigenous peoples and rules like World Bank OD 4.20 relate to the cultural autonomy of historically underprivileged, mobile, or minority groups within a sovereign nation-state, either due to the idea of primordial occupation, cultural uniqueness, and/or vulnerability (Bowen 2000). The stated ethical intent of a rule like OD 4.20 is to ensure that particular groups of people, be they 'indigenous peoples', ethnic minorities, or other groups whose social or economic status has historically restricted their ability to assert their interests and rights to land and other productive resources, are afforded special protections to avoid increased vulnerability disadvantage in the development process (World Bank 1991).

In accordance with World Bank funding policies, Mikea Forest environmental policies at times include laudable assertions recognizing historical inequities and contemporary vulnerabilities, and propose a governance structure in which Mikea people can become the agents of their own development on their own terms. For example, the Plan de gestion environnementale, Programme environnemental 3 clearly states that a Mikea Development Plan would be developed "by and for Mikea, who will define the plan and activities that they think are beneficial for their social, economic and cultural development," and pledges to not develop plans for a Mikea Forest PA until such a development plan is realized (Ministère de I'Environnement, des Eaux et Forêts 2003: 6-7), while the Cadre Stratégique pour le Développement des Populations Autochtones Mikea states that "Mikea people will ultimately decide on the opportunity to transform the forest into a PA" (WWF 2003: 8).
However, the development plan, the Plan pour le développement des populations Mikea (PDPM), was not published until 2010, after plans to establish the Mikea National Park had been underway for several years. According to the Cadre Stratégique (WWF 2003: 5), the formulation of the development plan was delayed due to conceptual and logistical challenges. The first challenge discussed related to the terms 'indigenous peoples' and 'development' as defined by Operational Directive 4.20. Specifically, this challenge related to uncertainty regarding the task of creating a development plan for an 'indigenous' group of people whilst ensuring that they could maintain cultural identity and lifestyle (WWF 2003). The second challenge was logistical. Because of a long historical memory of exploitation and violence, many Mikea are skeptical about the motives of state representatives and NGO employees and intentionally avoid outsiders who seek them out. Simply stated, the research team tasked with preparing the development plan did not actually have the opportunity to interact and discuss their tasks with a substantial number of self-identifying Mikea people because people ran away or otherwise avoided them. Therefore, the informed participation of Mikea people in the development of PA policies was not realized at the time.

Instead, informed participation was proposed as an ongoing process ultimately to be regulated by the intercommunal NGO, FiMaMi (Fikambanana Miaro ny Ala Mikea, or Society for the Protection of the Mikea Forest). The membership of FiMaMi comprises the elected mayors of 15 of 19 townships surrounding the Mikea Forest, and its official responsibilities include cooperative resource management and enforcement of environmental legislation, including a continued ban on hatsaky maize production, as well as monitoring environmental impact of economic activities in areas near Route Nationale 9. Since the inception of prohibition of hatsaky maize production, FiMaMi has been considered the de jure representative of Mikea (even though no members of FiMaMi self - identify as Mikea) and other resource users' interests in matters related to conservation and development policy and enforcement.

The authors of the PDPM claim that all categories of stakeholders, including the autochthonous population, participated in a public consultation process, that Mikea have contributed to the development of a system for monitoring social and environmental impacts of the PA and related development projects, that free, prior, and informed consent (FPIC) was sought, and that FiMaMi gave local consent for PA establishment (Repoblikan'i Madagasikara et al. 2010a).

However, this proposed governance framework is problematic, due in no small part to the fact that categories of stakeholders that are formalized in these policies do not reflect on-theground realities of cultural self-identification, nor of lifestyle in terms of subsistence and other economic activities. In fact, very little policy information is actually available to people who live in forest settlements. Many people who are affected by the new PA are aware of its existence in an abstract sense, but discussed frustration at the lack of specific policy information that is available to them, a perceived uneven enforcement of rules regarding resource use, and a lack of access to legal protection against banditry and corruption.

The distinctions drawn among essentialized categories of true Mikea, false Mikea, migrants and other residents may seem like common sense to employees of financial institutions, 
policy planners, and conservation workers who are not native to nor familiar with the Mikea Forest region, and may thus be unfamiliar with local norms of identity and lifestyle. But local notions of what makes one Mikea do not make the distinction between true and false, nor do any people living in the region resemble the representations of primitivism and difference that have rendered idealized Mikea as unique primitives in popular Malagasy culture or in development funding proposals. Essentialized distinctions among ecologically noble members of the 'autochtonous Mikea population' and destructive 'false Mikea,' migrants, and others are not meaningful locally and are thus impossible to operationalize in the enforcement of policy.

\section{CONCLUSIONS}

Discourses of rurality and discourses of Mikea indigeneity define communities of local actors and their associated entitlements in the context of the gradual development of the Mikea National Park in order to define legitimate claims to land and resources (Neumann 1997: 561). Issues related to the representation of 'communities' are not just a matter of abstract or academic interest; they are inevitably linked to problems and questions in the domains of policy and practice (Brosius et al. 1998: 165). Discourses represent knowledge regimes from which policy prescriptions and action flow (Adger et al. 2001: 684), and they connect knowledge and actions of agents on multiple scales of interaction. Different actors employ compelling policy narratives and discourses for different purposes, and explanations of environmental, social, and demographic change that become integrated into policy are likely to be those put forward by relatively powerful stakeholders (Kull 2002).

Because Malagasy people living in rural localities may have limited means to counter dominant narratives or participate fully in policy discussions, stakeholders possessing greater social power shape the context in which discussions about environmental governance and rights take place, can specify who is qualified to make decisions about environmental management, and can frame problems so that certain courses of action are justified while a variety of alternative perspectives and courses of action are never considered (Brosius 1999: 278, Kull 2002: 63-64). These processes carry profound practical implications in terms of human well-being in the context of regional conservation and development projects, and for environmental futures in the Mikea Forest region and throughout Madagascar.

International norms for indigenous human rights claim universal applicability (Bowen 2000), but the concept of 'indigenous peoples' is highly politicized, and is subject to local and national particularities (Pelican 2009: 53). Identifying who qualifies as indigenous can be problematic, especially when these categories are not meaningful to the people who are objects of policy action. Such problems are exacerbated when procedures for achieving free, prior, and informed consent for conservation and development projects are conceptually and logistically challenging to practitioners on the ground (Bowen 2000, Colchester and Ferrari 2007, Pelican 2009). They contribute to significant gaps among prescribed policy, realized legislation and protocols, and micro-regional conservation and development practice. This risks widening gaps between anticipated results (in terms of social outcomes, and for landscape and biodiversity preservation) and realized local outcomes for particular projects.
Rather than empowering people to "negotiate on equal terms with project proponents" as is the intent of guidelines such as World Bank Operational Directive 4.20 (Goodland 2004: 66), the discourse of Mikea indigeneity mystifies Mikea identity, and naturalizes material poorness and social marginalization that self-identifying Mikea often experience in the broader social context. The imagery of the pristine forager is compelling because it adds to the force of the crisis narrative - not only is the Mikea Forest under threat, but so too is the unique and vulnerable human capital that inhabits it. At the same time, discourses of rurality mark non-Mikea as environmentally unworthy subjects, generalized as invasive, irrational, and criminally harmful to Mikea and the Mikea Forest, justifying their exclusion from policy discussions, livelihoods and territory as well.

When local experience runs counter to more generalized conceptions of social life and human-environment interactions, questioning dominant discourses and adjusting policy and practice accordingly can enhance knowledge about particular phenomena and local processes, and lead to improved practice and outcomes. Practitioners developing and administering environmental protection policies in the Mikea Forest region can achieve more just and democratic policies, and can work to mitigate the unintended negative consequences of policies that are already in place. But better practice cannot be based on received wisdoms about cultural difference or indigenous environmentalism. Rather than basing policies on cultural distinctions that do not reflect locally salient norms of identity and lifestyle, PA policies should be amended to substantively foster respect for residents' dignity and human rights, including consideration of a broad range of people, regardless of self-identity, who are socially and economically vulnerable because of restricted capacity to assert their interests in a democratic manner. Immediate attention should be paid to establishing substantive means of sharing information, and to building the institutional capacity to address the security concerns of people who are currently living within or otherwise depend on the territory under protection. This includes livelihoods security, as well as security from violence and exploitation, ensuring that all people have free and equitable access to legal institutions.

\section{ACKNOWLEDGMENTS}

I would like to acknowledge reviewers for their detailed and helpful comments. I would also like to acknowledge and thank those living and working in the Mikea Forest region who contributed to this research. I would also like to acknowledge the support and guidance that I have received from professors and staff affiliated with Centre de Documentation et de Recherche sur l'Art et les Traditions Orales à Madagascar (CEDRATOM) as well as the immense contribution of members of the research team, Patricia Hajasoa, Rolland Lahiniriko, Gervais Tantely, Jean-Claude Alhayess, and Théodore Ramanovontsoa. I would also like to acknowledge Bram Tucker, Anne Sourdril, colleagues in the Behavioral Ecology and Economic Decisions lab at the University of Georgia, and the financial support of the National Science Foundation and the Fulbright Institute for International Education. 


\section{REFERENCES}

Adger, W. N., Benjaminsen, T. A., Brown, K. and Svarstad, H. 2001. Advancing a political ecology of global environmental discourses. Development and Change 32, 4: 681-715. (doi:10.1111/1467-7660.00222)

Anaya, S. J. 1991. Indigenous rights norms in contemporary international law. Arizona Journal of International and Comparative Law 8: 1-39.

Anaya, S. J. 2004. International human rights and indigenous peoples: The move toward the multicultural state. Arizona Journal of International and Comparative Law 21, 1: 13-61

Astuti, R. 1995a. People of the Sea: Identity and Descent among the Vezo of Madagascar. New York, Cambridge University Press.

Astuti, R. 1995b. The Vezo are not a kind of people: Identity, difference, and "ethnicity" among a fishing people of western Madagascar. American Ethnologist 22, 3: 464-482. (doi:10.1525/ae.1995.22.3.02a00010)

Astuti, R. 2000. Kindreds, cognatic and unilineal descent groups: New perspectives from Madagascar. In: Cultures of Relatedness: New Approaches to the Study of Kinship. J. Carsten (ed.), pp 90-103. Cambridge University Press, Cambridge.

Astuti, R. and Harris, P. 2008. Understanding mortality and the life of the ancestors in rural Madagascar. Cognitive Science 32, 4: 713-740. (doi:10.1080/03640210802066907)

Aubry, C. and A. Ramaromisy. 2003. Typology of farms in a village of the pioneer settlement area of the Mikea Forest (southwest of Madagascar). Cahiers Agricultures 12, 3: 153-165.

Batterbury, S. 2001. Landscapes of diversity: A local political ecology of livelihood diversification in southwestern Niger. Cultural Geographies 8: 437-464. (doi:10.1177/096746080100800404)

Berg, G. M. 1977. The myth of racial strife and Merina kinglists: The transformation of texts. History in Africa 4: 1-30.

Birkeli, E. 1920. The Bantu in Madagascar: The Malagasy race affinity. Journal of the Royal African Society 19: 305-316.

Birkeli, E. 1936. À la recherche des Vazimba, des Beosi et des Mikea de la côte ouest de Madagascar. Mémoires de l'Académie Malgache: 7-13.

Blanc-Pamard, C. 2002. Territoire et patrimoine dans le Sud-Ouest de Madagascar: une construction sociale. In: Patrimonialiser la Nature Tropicale. M. C. Cormier-Salem (ed.), pp 215-243. IRD, Paris.

Blanc-Pamard, C. 2009. The Mikea Forest under threat (southwest Madagascar): How public policy leads to conflicting territories. Field Actions Science Report. Available at <http://factsreports.revues. org/341>

Blanc-Pamard, C., Milleville, P., Grouzis, M., Lasry F. \& Razanaka, S. 2005 Une alliance de disciplines sur une question environnementale: la déforestation en forêt des Mikea (Sud-Ouest de Madagascar). Natures Sciences Sociétés 13, 1: 7-20. (doi:10.1051/nss:2005002)

Blench, R. 2008. The Austronesians in Madagascar and their interaction with the Bantu of the East African coast: Surveying the linguistic evidence for domestic and translocated animals. Studies in Philippine Languages and Cultures 18: 18-43.

Bloch, M. 1971. Placing the Dead: Tombs, Ancestral Villages, and Kinship Organization in Madagascar. Seminar Press, New York.

Bodin, Ö., Tengö, M., Norman, A., Lundberg, J. and Elmqvist, T. 2006. The value of small size: Loss of forest patches and ecological thresholds in southern Madagascar. Ecological Applications 16, 2: 440-451.

Bowen, J. R. 2000. Should we have a universal concept of 'indigenous peoples' rights'?: Ethnicity and essentialism in the twenty-first century. Anthropology Today 16, 4: 12-16.

Brosius, J. P. 1999. Analyses and interventions: Anthropological engagements with environmentalism. Current Anthropology 40, 3: 277-310. (doi:10.1086/200019)

Brosius, J. P., Tsing, A. L. and Zerner, C. 1998. Representing communities: Histories and politics of community-based natural resource management. Society and Natural Resources 11, 2: 157-168. (doi:10.1080/08941929809381069)

Campbell, G. 1992. Crisis of faith and colonial conquest: the impact of famine and disease in late nineteenth-century Madagascar. Cahiers d'Études Africaines 32, 127: 409-453.

Coe, M. 1998. Review: Ecology and economy of a tropical dry forest in Madagascar (Edited by Ganzhorn, J. U. and Sorg, J.-P.). Biodiversity Conservation 83, 2: 232
Colchester, M. and Ferrari, M. F. 2007. Free, Prior and Informed Consent: Making FPIC work for forests and peoples. The Forest Dialogue, New Haven. Available at <http://dspace.cigilibrary.org/jspui/handle/123456789/26127>

Cole, J. 2001. Forget Colonialism? Sacrifice and the Art of Memory in Madagascar. University of California Press, Berkeley, CA.

Dear, C. and McCool, S. 2010. Causes and consequences of displacement decision-making in Banhine National Park, Mozambique. Conservation and Society 8, 2: 103-111. (doi:10.4103/0972-4923.68910)

Dina, J. 2001. The hazomanga among the Masikoro of southwest Madagascar: Identity and history. Ethnohistory 48, 1-2: 13-30. (doi:10.1215/00141801-48-1-2-13)

Dugal, S. J. 2004. What's the Story with Vazimba?: Oral History, Social Change, and Identity in Highland Madagascar. Unpubl. Ph.D. thesis. Tulane University, New Orleans.

Durbin, J. 1999. Lemurs as flagships for conservation in Madagascar. In: New Directions in Lemur Studies. B. Rakotosamimanana, H. Rasamimanana, J. Ganzhorn and S. Goodman (eds.), pp 269-295. Kluwer Academic/ Plenum Publishers, New York.

Emoff, R. 2002. Recollecting from the Past: Musical Practice and Spirit Possession on the East Coast of Madagascar. Wesleyan University Press, Middletown, CT.

Faroux, E. \& Rabedimy, J.-F. 1985. Note sur un groupe "Mikea" de la région de Salara. Équipe de Recherche Associée Ministère de la Recherche Scientifique et Technologique pour le Développement/ORSTOM.

Feeley-Harnik, G. 1986. Ritual and work in Madagascar. In: Madagascar Society and History. C. Kottak, J.-A. Rakotoarisoa, A. Southall and P. Vérin (eds.), pp 157-174. Carolina Academic Press, Durham, NC.

Ferguson, B. 2009. REDD comes into fashion in Madagascar. Madagascar Conservation \& Development 4, 1: 132-137.

Foiben-Taosarintanin'i Madagasikara \& Madagascar National Parks. 2009 Carte de Zonage du Parc National Mikea (PNMKA). FTM, Toliara, Madagascar.

Ganzhorn, J. U., Lowry II, P. P., Schatz, G. E. and Sommer, S. 2001. The biodiversity of Madagascar: One of the worldıs hottest hotspots on its way out. Oryx 35, 4: 346-348. (doi:10.1046/j.1365-3008.2001.00201.x)

Goedefroit, S. 1998. À I'ouest de Madagascar: Les Sakalava du Menabe. Karthala-IRD, Paris.

Goodland, R. 2004. Free, prior and informed consent and the World Bank Group. Sustainable Development Law \& Policy 4, 2: 66-74.

Graeber, D. 1999. Painful memories. In: Ancestors, Power and History in Madagascar. K. Middleton (ed.), pp 319-365. Brill, Leiden.

Graeber, D. 2007. Lost People: Magic and the Legacy of Slavery in Madagascar. Indiana University Press, Bloomington.

Grandidier, G. 1920. Madagascar. Geographical Review 10: 197-222.

Hannah, L., Rakotosamimanana, B., Ganzhorn, J., Mittermeier, R. A., Olivieri, S., Iyer, L., Rajaobelina, S., Hough, J., Andriamialisoa, F., Bowles, I. and Tilkin, G. 1998. Participatory planning, scientific priorities, and landscape conservation in Madagascar. Environmental Conservation 25, 1: 30-36.

Hardin, G. 1968. The tragedy of the commons. Science 162, 3859: 1243-1248. (doi:10.1126/science.162.3859.1243)

Harper, G. J., Steininger, M. K., Tucker, C. J., Juhn, D. and Hawkins, F. 2007. Fifty years of deforestation and forest fragmentation in Madagascar. Environmental Conservation 34, 4: 1-9. (doi:10.1017/ S0376892907004262)

Herzfeld, M. 1998. Factual fissures: Claims and contexts. Annals of the American Academy of Political and Social Science 560: 69-82.

Herzfeld, M. 2001. Anthropology: Theoretical Practice in Culture and Society. Blackwell Publishers Inc., Malden, MA.

Hodgson, D. L. 2002. Introduction: Comparative perspectives on the indigenous rights movement in Africa and the Americas. American Anthropologist 104, 4: 1037-1049. (doi:10.1525/aa.2002.104.4.1037)

Hoerner, J. M. 1981. Tuléar et le Sud-ouest de Madagascar: Approche Démographique. Madagascar Revue de Géographie 39: 9-49.

Hoerner, J. M. 1987. Le «boom» de coton de 1982 à 1986 In: M. Fieloux \& J. Lombard (eds.). Études des Transformations Socio-Économiques dans le Sud-ouest Malgache: L'Exemple du Couloir Antseva. MRSTD/ORSTOM, Antananarivo/Paris. 
Kelly, R. L. and L. Poyer. 1999. The Mikea of Madagascar. In: The Cambridge Encyclopedia of Hunters and Gatherers. R. B. Lee and R. Daly (eds.), pp 215-219. Cambridge University Press, Cambridge.

Koechlin, B. 1975. Les Vezo du Sud-ouest de Madagascar, contribution à liétude de liécosystème de semi-nomades marins. Cahier de l'Homme 15: $51-54$

Kull, C. 2002. The "degraded" Tapia woodlands of highland Madagascar: Rural economy, fire ecology, and forest conservation. Journal of Cultural Geography 19, 2: 95-128. (doi:10.1080/08873630209478290)

Lambek, M. 1998. The Sakalava poiesis of history: Realizing the past through spirit possession in Madagascar. American Ethnologist 25, 2: 106-127. (doi:10.1525/ae.1998.25.2.106)

Lambek, M. and Walsh, A. 1997. The imagined community of Antankarana: Identity, history, and ritual in northern Madagascar. Journal of Religion in Africa 27, 3: 308-333

Laurance, W. F. 1999. Reflections on the tropical deforestation crisis Biological Conservation 91, 2-3: 109-117. (doi:10.1016/S00063207(99)00088-9)

Leach, M. and Mearns, R. 1996. Environmental change and policy. In: The Lie of the Land: Challenging Received Wisdom on the African Environment. M. Leach and R. Mearns (eds.), pp 1-33. James Currey Press, Oxford.

Lee, R. B. and Hitchcock, R. K. 2001. African hunter-gatherers: Survival, history and the politics of identity. African Study Monographs 26 (Suppl.): 257-280.

Malzac, V. \& Callet, F. 1908. Tantara ny Andriana eto Madagascar. Imprimerie Officielle, Paris.

Middleton, K. 1999. Who killed «Malagasy cactus`? Science, environment and colonialism in southern Madagascar. Journal of Southern African Studies 25, 2: 215-248. (doi:10.1080/030570799108678)

Milleville, P., Grouzis, M. C., Razanaka, S. \& Bertrand, M. 2001. La culture pionnière du maïs sur abattis-brûlis (hatsaky) dans le sud-ouest de Madagascar. Pages 255-268 In: S. Razanaka, M. Grouzis, P. Milleville, B. Moizo \& C. Aubry, editors. Sociétés Paysannes, Transitions Agraires et Dynamiques Écologiques dans le Sud-ouest de Madagascar. CNRE/IRD, Antananarivo.

Ministère de l'Environnement, des Eaux et Forêts. 2003. Plan de gestion environnementale, Programme environnemental 3 (E850, vol.3). Repoblikan'i Madagasikara, Antananarivo.

Mittermeier, R. A., Ganzhorn, J. U., Konstant, W. R., Glander, K., Tattersall, I., et al. 2008. Lemur diversity in Madagascar. International Journal of Primatology 29, 6: 1607-1656. (doi:10.1007/s10764-008-9317-y)

Mouyon, J.-C. \& Francelle, P. 1999a. Au sud-ouest de la Grande île, feu, les Mikea. Korail: Magazine de la Coopération Régionale 32: 44-47.

Mouyon, J.-C. \& Francelle, P. 1999b. Feu Mikea. L'Express de Madagascar, 29 June 1999.

Myers, N. 1992. Tropical forests: The policy challenge. The Environmentalist 12, 1: 15-27. (doi:10.1007/BF01267592)

Myers, N., Mittermeier, R. A., Mittermeier, C. G., da Fonesca, G. A. B. and Kent, J. 2000. Biodiversity hotspots for conservation priorities. Nature 403: 853-858. (doi:10.1038/35002501)

Neumann, R. 1997. Primitive ideas: Protected area buffer zones and the politics of land in Africa. Development and Change 28, 3: 559-582. (doi:10.1111/1467-7660.00054)

Norris, S. 2006. Madagascar defiant. Bioscience 56, 12: 960-965. (doi:10.1641/0006-3568(2006)56[960:MD]2.0.C0;2)

Ottino, P. 1963. Les Économies Paysannes Malgaches du Bas-Mangoky. Éditions Berger-Levrault, Paris

Pelican, M. 2009. Complexities of indigeneity and autochthony: An African example. American Ethnologist 36, 1: 52-65. (doi:10.1111/j.15481425.2008.01109.x)

Pratt, A. C. 1996. Discourses of rurality: loose talk or social struggle. Journal of Rural Studies 12,1: 69-78. (doi:10.1016/0743-0167(95)00046-1)

Poyer, L. and Kelly, R. L. 2000. Mystification of the Mikea: Constructions of foraging identity in southwest Madagascar. Journal of Anthropological Research 56, 2: 162-185.
Raik, D. 2007. Forest management in Madagascar: An historical overview. Madagascar Conservation \& Development 2: 5-10.

Rarojo, J. 1998. Ny Mikea: tsy lolo. Vintsy 26: 4-7.

Redford, K. 1991. The ecologically noble savage. Orion Nature Quarterly 9, 3: 25-29.

Repoblikan'i Madagasikara. 2007. Arrêté interministériel N.5569/2007 portant protection temporaire de lraire protégée en création dénommée "Complexe Mikea ». Antananarivo : Ministère de l'Environnement, des Eaux et Forêts ; Ministère de l'Agriculture, de l'Élevage et de la Pêche ; Ministère de l'Énergie ; Ministère des mines.

Repoblikan'i Madagasikara, Ministère de l'Environnement, des Eaux et Forêts \& Madagascar National Parks. 2010a. Plan de Développement de la Population Autochtone Mikea, vol. 2. World Bank.

Repoblikan'i Madagasikara, Ministère de I'Environnement, des Eaux et Forêts \& Madagascar National Parks. 2010b. Cadre Fonctionnel de Procédures de Sauvegarde pour le Projet de Création du Parc National Mikea, vol. 3. World Bank.

Reyneke, L. and Wallmach, T. 2007. Characterization of FeTi-oxide species occurring in Ranobe heavy mineral deposit, Madagascar. The 6th International Heavy Minerals Conference: Back to Basics. The South African Institute of Mining and Metallurgy, South Africa.

Ruud, J. 1960. Taboo: A Study of Malagasy Customs and Beliefs. Oslo University Press, Oslo.

Sarafaty, G. A. 2005. The World Bank and the internalization of indigenous rights norms. The Yale Law Journal 114, 7: 1791-1818.

Seddon, N., Buchart, S., Tobias, J., Yount, J. W., Ramanampamonjy, J. R. and Randrianizahana, H. 2000. Conservation issues and priorities in the Mikea Forest of south-west Madagascar. Oryx 34, 4: 287-304. (doi:10.1046/j.1365-3008.2000.00134.x)

Sharp, L. A. 1995. Playboy princely spirits of Madagascar: Possession as youthful commentary and social critique. Anthropological Quarterly 68, 2: 75-88.

Sirven, N. 2006. Endogenous social capital and self-rated health: Crosssectional data from rural areas of Madagascar. Social Science \& Medicine 63, 6: 1489-1502. (doi:10.1016/j.socscimed.2006.04.003)

Smith, A. P., Horning, N. and Moore, D. 1997. Regional biodiversity planning and lemur conservation in western Madagascar. Conservation Biology 11, 2: 498-512. (doi:10.1046/j.1523-1739.1997.95283.x)

Stiles, D. 1991. Tubers and tenrecs: The Mikea of southwestern Madagascar. Ethnology 30, 3: 251-263.

Stiles, D. 1998. The Mikea hunter-gatherers of southwest Madagascar: Ecology and socioeconomics. African Study Monographs 19, 3 : $127-148$.

Styger, E., Rakotoarimanana, J. E. M., Rabevohitra, R. and Fernandes, E. C. M. 1999. Indigenous fruit trees of Madagascar: Potential components of agroforestry systems to improve human nutrition and restore biological diversity. Agroforestry Systems 46, 3: 289-310. (doi:10.1023/A:1006295530509)

Tucker, B. 2001. The behavioral ecology and economics of variation, risk, and diversification among Mikea forager-farmers of Madagascar. Unpubl. Ph.D. thesis. University of North Carolina at Chapel Hill, Chapel Hill.

Tucker, B. 2003. Mikea origins: Relics or refugees? In: Love/Inheritance: Past and Present in Madagascar. Z. Crossland, G. Sodikoff and W. Griffen (eds.), pp 194-215. Michigan Discussions in Anthropology.

Tucker, B., Huff, A., Tsiazonera, Tombo, J., Hajasoa, P. and Nagnisaha, C. 2011. When the wealthy are poor: Poverty explanations and local perspectives in southwestern Madagascar. American Anthropologist 113, 2: 291-305. (doi:10.1111/j.1548-1433.2011.01331.x)

Wilmsen, E. N. 1989. Land Filled With Flies: A Political Economy of the Kalahari. The University of Chicago Press, Chicago.

WorldBank. 1991. Operational Directive 4.20: Indigenous Peoples in W. Bank, editor. World Bank, Geneva.

WWF. 2003. Cadre Stratégique pour le Développement des Populations Autochtones Mikea. World Bank and République de Madagascar, Antananarivo, Madagascar. 
Yount, J. W., Tsiazonera and Tucker, B. T. 2001. Constructing Mikea identity: Past or present links to forest and foraging. Ethnohistory 48, 1-2: 257-291. (doi:10.1215/00141801-48-1-2-257)

Zeller, M., Lapenu, C., Minten, B., Ralison, E., Randrianaivo, D. and Randrianarisoa, C. 2000. Pathways of rural development in Madagascar: An empirical investigation of the critical triangle of environmental sustainability, economic growth, and poverty alleviation. FCND discussion paper no. 82. Food Consumption and Nutrition Division, International Food Policy Research Institute, Washington, DC.

\section{ENDNOTES}

1. In this discussion, the term 'Vazimba' refers specifically to the tradition claiming that an ancient race of African origin lived in Imerina before the arrival of proto-Malagasy settlers from the Malay peninsula, later driven from the central highlands by early Malagasy kings. There are a number of different Vazimba traditions in oral history and text, including those documented by Dugal (2004), Berg (1977), and countless amateur oral historians working and living in Imerina in the pre-colonial period. This discussion does not refer to members of Vazimba people of the Menabe described by Ruud (1960), members of the Vazimba clan of the northern Fihereña, nor to descendants of 'lost people', former slaves living in Imerina who used ritual ties with Vazimba spirits and claims of personal Vazimba ancestry to stake claim to burial in the historical landscape (Graeber 1999, 2007). 